\title{
Economic Geography within and between European Nations: The Role of Market Potential and Density across Space and Time
}

\author{
STEVEN BRAKMAN \\ HARRY GARRETSEN \\ CHARLES VAN MARREWIJK
}

CESIFO WORKING PAPER No. 2658

CATEGORY 12: EMPIRICAL AND THEORETICAL METHODS

MAY 2009

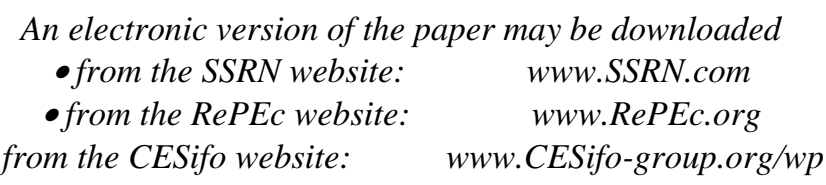




\title{
Economic Geography within and between European Nations: The Role of Market Potential and Density across Space and Time
}

\begin{abstract}
In explaining the uneven spatial distribution of economic activity, urban economics and new economic geography (NEG) dominate recent research in economics. A main difference between these two approaches is that NEG stresses the role of spatial linkages whereas urban economics does not do so. We estimate simple versions of these two views on economic geography and also establish if the relevance of spatial linkages varies across aggregation levels or time. For our sample of 14 European countries and 213 corresponding regions, we find that spatial linkages are more important at the country level and that its relevance varies across time.
\end{abstract}

JEL Code: F12, F13, R11, R15.

Steven Brakman
Faculty of Economics and Business
University of Groningen
PO Box 800
9700 AV Groningen
The Netherlands
S.Brakman@rug.nl
Charles van Marrewijk
Harry Garretsen
Faculty of Economics and Business
University of Groningen
PO Box 800
9700 AV Groningen
The Netherlands
J.H.Garretsen@rug.nl of Economics

First version: October 2008; Revised version: April 2009

An earlier version of this paper was presented at the conference "Are cities more important than countries?", 30 and 31 October 2008, Erasmus University Rotterdam, the Netherlands. We are grateful to Maarten Bosker, Phil McCann, Gianmarco Ottaviano, Stephen Redding, Julia Swart, Jacques Thisse, the other conference participants, Mark Partridge and two anonymous referees for useful comments and suggestions. 


\section{$1 \quad$ Introduction}

In urban economics, cities or regions are like freely floating islands (Fujita and Mori, 2005) since spatial or "inter-city" interdependencies are typically not taken into account. ${ }^{2}$ In new economic geography (NEG), the interregional interdependencies are, however, at the heart of the analysis and this sets NEG apart from urban economics. This difference as to the understanding of the actual economic geography provides an opportunity to analyse the empirical relevance of these two views on economic geography (Combes, Duranton and Overman, 2005).

If the attractiveness of a region is best described by intraregional characteristics, this is evidence in favour of the urban economics' view on economic geography. If, in contrast, the interregional linkages are more relevant this provides evidence in favour of a view on economic geography like NEG that stresses spatial linkages between locations. Furthermore, the relevance of these two views could depend on the level of spatial aggregation or vary over time. Combes, Duranton, and Overman (2005) for instance argue that NEG is probably more relevant at the country level than at the regional or urban level. Data on different aggregation levels could thus help to reveal whether or not the explanatory power of the two approaches depends on the spatial aggregation level. The relevance of spatial linkages might also change over time, depending on policies or shocks that occur.

Using a data set for 14 European countries and a corresponding set of 213 (NUTSII) regions, we address the issues introduced above: the relevance of interregional vs intraregional economic geography, and the influence of spatial aggregation levels and the time period under consideration on these two views on economic geography. In doing so, we take the basic message of Leamer and Levinsohn (1995, p.1341) "estimate don't test" seriously. So, our paper is not meant as a test of urban economics versus NEG but rather we want to fund out how relevant spatial linkages actually are for our European case at hand. We also take their second message "don't treat theory too casually" seriously and hence explain how our two basic empirical specifications can be grounded upon economic theory.

In section 2 we explain the difference between urban economics and NEG in somewhat more detail and position our paper in the literature. In section 3 we

\footnotetext{
${ }^{2}$ See for instance the special issue of the Federal Reserve Bank of New York (2005) on urban dynamics in New York City that offers detailed information on urban aspects of New York at an impressively small scale.
} 
introduce the two basic empirical specifications and indicate how they can be derived from NEG and urban economics. In section 4 we describe the data-set and present some descriptive statistics. Section 5 presents the main estimation results for the period 1975-2006, the period for which we have data for countries as well as NUTSII regions. In general, we find that spatial linkages or "between location" economic geography is more important at the country level than at the regional level. Section 6 presents additional estimation results for the 14 European countries for the period 1870-2006. Section 7 concludes.

\section{Economic geography in urban economics and NEG}

In their excellent survey of agglomeration theory, Ottaviano and Thisse (2004, p.2576) ask the question "where did we stand in 1990?", which is to say prior to the publication of the first NEG model by Krugman (1991). They observe that Krugman (1980) already incorporated (internal) increasing returns to scale and transport costs that together constitute the fundamental trade-off in spatial economics (Fujita and Thisse, 2002) and that together also give the foundation for the well-known home market effect in Krugman (1980). In Krugman (1991), the home market effect is combined with interregional factor (labor) mobility and thus endogenizes the spatial distribution of economic activity. Krugman (1991) and the subsequent NEG literature can in fact be seen as belonging to a much more extensive (and older) literature in regional economics or even economic geography at large, where spatial interdependencies are at the heart of the analysis. The performance of a region depends crucially on the developments in and characteristics of neighboring regions. Regions are therefore not "freely floating islands" in NEG (Fujita and Mori 2005, p. 395). ${ }^{3}$ This non-trivial role of spatial linkages amounts to saying that it is above all "between location" economic geography that matters in (old and) NEG. A key prediction of NEG models is that inter alia factor prices (wages) are higher in regions with a large (real) market potential. ${ }^{4}$ This prediction will be used in our empirical estimations.

\footnotetext{
${ }^{3}$ For surveys of NEG see Baldwin et al. (2003), Combes, Mayer and Thisse. (2008), or Brakman, Garretsen and van Marrewijk (2009).

${ }^{4}$ A large market will attract firms and workers to the increasing returns sector; if labor supply from the constant returns sector is upward sloping (concave production function) economy wide increases of factor rewards are possible (see Head and Mayer, 2004 for a discussion).
} 
A rather different view on the role of economic geography is offered by urban economics, where spatial or "inter-city" interdependencies are typically not taken into account. ${ }^{5}$ Transport costs or distances between locations are not included in the analysis. Economic geography in the sense of spatial interdependencies between cities is at best implicitly taken into account like in Henderson's seminal model of urban systems (Henderson, 1974). In this model, cities specialize and trade with each other, but intercity distances do not matter and non-urban areas also play no role (Glaeser, 2008, ch. 3, Combes, Duranton and Overman, 2005). Apart from the well-known Marshallian scale economies, there is a whole range of scale economies that is called upon to explain the existence of cities and their variation in size (Rosenthal and Strange, 2004; Overman, Rice and Venables, 2008). ${ }^{6}$ Compared to NEG, urban economics offers a more detailed analysis of location (city) specific agglomeration economies. This holds not only for positive but also for negative agglomeration (congestion) economies (see for an extensive survey Rosenthal and Strange, 2004 or Glaeser, 2008).

Despite their different stance on economic geography, the underlying NEG and urban economics models are analytically quite similar. In NEG models, economic geography can be decomposed into the economic geography of the home or own region and the economic geography of the relationship between the own region and the other regions (compare also the discussion of equations (1) and (3) in the next section). Given the theoretical "kinship" between the seminal urban economics and NEG model of Henderson (1974) and Krugman (1991) respectively, Combes, Duranton and Overman (2005) conclude that in the end it is an empirical question which model is applicable in which situation. ${ }^{7}$ They argue that NEG is probably more relevant at a larger spatial scale where spatial interdependencies between locations are thought to be more important. Urban economics is thought to be more relevant at smaller spatial scales (regions or cities), where local (positive and negative) externalities are most important and between-city interactions and long distance relations are less important: "we would argue that there is no inherent contradiction between the urban system approach and NEG: the latter is trying to explain broad

\footnotetext{
${ }^{5}$ Note that this does not imply that regions do not sell or buy from other regions, only that costs or income are not dependent on the specific location of an 'island'.

${ }^{6}$ The standard analysis of the sources of (Marshallian) externalities is not without its problems, see Duranton and Puga (2004).

${ }^{7}$ See for a similar conclusion Combes et al (2006) and Overman, Rice and Venables (2008).
} 
trends at large spatial scales while the former attempts to explain "spikes" of economic activity" (Combes, Duranton and Overman, 2005, p.330).

Empirical studies that systematically try to assess the relative importance of intraregional vs interregional economic geography are scarce. Typically, empirical studies focus on either interregional or spatial linkages like the NEG studies by Hanson (2005) or Redding and Venables (2004) or exclusively on intraregional or own-region variables as is the case in modern empirical urban economics (see Glaeser, 2008). There are some NEG studies that also include an urban economics variable like density (Breinlich, 2006), and there are also a few empirical urban economics papers that do likewise by taking spatial linkages into account (Ciccone (2002), Duranton and Overman (2005)). But there are to date just a handful of papers that give equal importance to both approaches to economic geography. Fingleton (2006) is an exception but he focuses on one spatial scale (UK regions) and on a relatively short time period only. Other recent important empirical studies that combine urban economics with (NEG) spatial linkages include Brülhart and Koenig (2006), Brülhart and Sbergami (2009), Eaton and Eckstein (1997) and Partridge et al (2008, 2009). Even though these studies differ in their empirical methodology and scope, they all convincingly show the importance of including both urban(ization) variables and spatial agglomeration variables.

Just like Fingleton (2006), our paper mainly differs from these studies because of our focus on the role of geographical scale and the time dimension. More specifically, we focus on two spatial scales (14 European countries for 1870-2006 and, from 1975 onwards, the corresponding NUTSII regions). One of the (justified) criticisms levied against NEG from, for instance "proper" economic geography (Martin, 1999, 2008), is that NEG models are scale invariant. We want to establish if indeed the relative strength of intraregional and interregional economic geography is scale-dependent. Are the spatial interdependencies emphasized by NEG indeed more relevant at the national level? Apart from the possibility of scale-dependency, we also want to find out if the strength of within and between region economic geography varies over time. Many of the empirical studies in urban economics or NEG (mainly) take a cross-section perspective, whereas spatial linkages may vary over time. One could for instance stipulate that spatial interdependencies become more important during periods of economic and political integration. 


\section{The wage equation and the use of density and market potential}

The aim of this section is to briefly outline how our main empirical specifications can be based on urban economics or NEG models. We start with the urban economics approach and then concentrate on NEG. A simple model that is useful for our present purposes is conveniently summarized by Combes, Mayer and Thisse (2008, ch 11). Assume a profit maximizing firm with a Cobb-Douglas production function that uses labor and a (composite) of other inputs and that has all other markets as destination markets and maximizes profits. This firm pays the following wage ${ }^{8}$ :

$$
w_{r}=\frac{\mu(1-\mu)^{(1-\mu) / \mu}}{n_{r}} \sum_{j \in n_{r}} s_{j}\left(\frac{p_{j} A_{j}}{q_{j}^{1-\mu}}\right)^{1 / \mu}
$$

where $w_{r}=$ wage in region $r ; j=$ firm $j ; \mu=$ share of labor in the production process; $n_{r}=$ the number of firms in region $r ; s_{j}=$ labor productivity variable; $p_{j}=$ price of $\operatorname{good} j ; A_{j}=$ technology (Hicks-Neutral); $q_{j}=$ price of (composite of) other inputs.

Equation (1) shows that wages in region $r$ increase when the efficiency of labor $s_{j}$ or the level of technology $A_{j}$ increase in this region. Note that the overall impact of $s_{j}$ and $A_{j}$, on wages in region $r$ is a positive function of the number of firms $j$ that are located in region $r$. This reflects region specific, positive agglomeration economies in region $r$. Also, an increased supply of intermediate production factors that results in lower intermediate product prices $q_{j}$ allows for higher wages. The agglomeration of firms in region $r$ also has its downside: more competition means a higher $n_{r}$ and a lower $p_{j}$ and this will result in lower wages. Firms in region $r$ can sell their products to other regions, but the location of region $r$ relative to other regions is not an issue, hence spatial linkages between regions $r$ are absent, equation (1) only includes local, regionspecific determinants of regional wages.

For empirical research, the main question is how to estimate equation (1). A straightforward procedure is as follows (again see also Combes, Mayer and Thisse, 2008, ch11). Taking logs of equation (1) gives:

$$
\ln w_{r}=\alpha_{1}+\alpha_{2} \ln \text { Dens }_{r}+\varepsilon_{r},
$$

where $\ln$ Dens $_{r}=\ln \frac{1}{n_{r}} \sum_{j \in n_{r}} s_{j}\left(\frac{p_{j} A_{j}}{q_{j}^{1-\mu}}\right)^{1 / \mu}$ and Dens $r_{r}$ stands for the employment or population density in region $r$.

\footnotetext{
${ }^{8}$ See appendix A for the derivation of equation (1)
} 
Apart from the potential impact of density, there are other variables that may be included as well. In a panel setting, the inclusion of region (city) fixed effects and time fixed effects captures the possible relevance of, respectively, cross-section and time-specific variation in regional wages. But just like in the case of a density measure, there may be other location-specific determinants of region wages that vary in the cross-section as well as the time dimension, like human capital or a region's economic specialization, that one may want to include in the estimation (see Overman, Rice and Venables 2008, eq. 8). ${ }^{9}$ For our paper it is, however, imperative to note that equations (1) and (2) do not include variables that capture the spatial interdependencies between regions in the sense that somehow other regions have an impact on the wages in region $r$.

Ever since Harris (1954), market potential variables have been used in economic geography to capture the role of interregional spatial linkages. NEG provides a theoretical foundation for the use of market potential. In empirical applications Harris's simple market potential function is, however, still a good starting point as we will illustrate below. The equilibrium wage equation in NEG is the counterpart to wage equation (1) above. Equation (3) summarizes the by now well-known NEG wage equation ${ }^{10}$ :

$$
\ln w_{r}=\frac{1}{\sigma} \ln R M P_{r}-\frac{1}{\sigma} \ln \left(\frac{a}{c}\right),
$$

where $R M P_{r}=\sum_{s} \phi_{r s} \delta_{s} Y_{s} P_{s}^{\sigma-1}$, with $\phi_{r s}=\tau_{r s}^{-(\sigma-1)}, a=$ constant, $c=\sigma^{-\sigma} /(\sigma-1)^{-(\sigma-1)}$; $\delta_{\mathrm{s}}=$ the share of income spent on manufacturing goods in region $s, Y_{S}=$ income in region $s ; P_{s}=$ manufacturing price index; $\tau_{r s}=$ the iceberg transportation costs between regions $r$ and $s ; \sigma=$ elasticity of substitution between manufacturing varieties with $\sigma>1$

Equation (3) states that equilibrium wages in region $r$ depend on $R M P$ which stands for real market potential. This term captures the element of spatial linkages. Regions might be attractive because they represent a large market, reflected by $\delta_{s} Y_{s}$, but if it costly to trade with other regions, reflected by a low free-ness of trade, $\phi_{r s}=\tau_{r s}^{-(\sigma-1)}$, the market potential of region $r$ is reduced. Together these two forces determine the nominal market potential of a region $r$. The inclusion of a price index $P$ is responsible

\footnotetext{
${ }^{9}$ Ideally, one would like to have micro-data to estimate equation (2), see Combes, Duranton and Gobillon (2008).

${ }^{10}$ See appendix A for a derivation of equation (3).
} 
for the 'real' in $R M P$. Our main concern is that equation (3) differs fundamentally from equation (1) because the location of a specific region is defined with respect to all other regions. The presence of spatial linkages (via the free-ness of trade) ensures that wages in region $r$ (also) depend on the (real) income in other regions and the proximitiy of these regions.

Some difficulties that arise when using equation (3) for empirical purposes are, however, immediately clear. Trade or transport costs have to be approximated by a trade costs function because of the lack of (sufficient) transport data (Bosker and Garretsen, 2008). For regions, price indices are typically not available. Many estimates of NEG wage equations try to fix these and other problems (see Combes and Overman, 2004, Head and Mayer, 2004, Combes, Mayer and Thisse, 2008, ch. 12, or Brakman, Garretsen, and Van Marrewijk, 2009, ch. 5 for a survey of these attempts). Just like in the case of equation (1), when estimating equation (3) one should include other explanatory variables as well. Apart from time and region fixed effects, human capital and density(!) have for instance been included (Breinlich, 2006, Hering and Poncet, 2006). ${ }^{11}$ As a first pass (and driven by data availability, see section 4), we reformulate equation (3) in terms of Harris's simple market potential, where we proxy $R M P$ from equation (3) by distance-weighted real income $M P$ :

$$
\ln w_{r}=\beta_{1}+\beta_{2} \ln M P_{r}+\varepsilon_{r} \text {, with } M P_{r}=\sum_{s} \frac{\delta_{s} Y_{s}}{d_{r s}} \text { and } d_{r s}=1 / \phi_{r s} .
$$

Note finally that according to the model used to arrive at equation (3), $(R) M P$ should include the own region's income. In order to distinguish own region effects from foreign region effects, we distinguish between domestic and foreign MP where foreign $M P$ excludes the own region. This provides the clearest contrast with wage equation (2).

\section{$4 \quad$ Data set and summary statistics}

We examine (changes over time) in the degree of spatial linkages at two different levels of aggregation within Europe. In doing so, we decided to restrict our sample to 14 European countries for the period 1870-2006 and to (if applicable) the corresponding 213 NUTSII regions (NUTS data are only available from 1975 onwards). The main data source for the country data is Maddison (2008). For the

\footnotetext{
${ }^{11}$ Density can be looked upon in terms of equation (3) as controlling for the fact that technology differs across regions.
} 
regions we use data from Eurostat and Cambridge Econometrics. Our choice to cover both countries and regions and to do so for a rather long time-period has drawbacks as well. The main drawback is lack of (sufficient) data for some of the (control) variables that one might want to include, like (regional) price indices or human capital. In addition, regional data for the EU NUTSII regions only exist from the mid1970s onwards. Similarly, and following for instance Redding and Venables (2004), we lack sufficient data on wages and therefore use GDP per capita instead.

Using the data set of Maddison (2008), we selected 14 countries in Europe for which annual data on income (GDP) and population (POP) are available for the period 1870-2006, see Table 1 below. The 14 countries are Austria, Belgium, Denmark, Finland, France, Germany, Italy, The Netherlands, Norway, Sweden, Switzerland, UK, Portugal and Spain.

Table 1 European countries; summary statistics, 1870-2006

\begin{tabular}{l|cccc}
\hline \hline & $\ln$ (for mar pot) & $\ln ($ gdp/cap) & $\ln$ (pop dens) & $\ln$ (urb pop dens) \\
\hline Mean & 4.97 & 8.52 & 4.25 & 3.42 \\
St. error & 0.023 & 0.019 & 0.025 & 0.033 \\
Median & 4.79 & 8.36 & 4.50 & 3.67 \\
Kurtosis & -0.92 & -1.09 & -0.48 & -0.16 \\
Skewness & 0.28 & 0.21 & -0.78 & -0.68 \\
Minimum & 2.91 & 6.84 & 1.65 & -0.53 \\
Maximum & 7.37 & 10.24 & 5.98 & 5.76 \\
Count & 1,918 & 1,918 & 1,918 & 1,918 \\
\hline
\end{tabular}

Correlation coefficients

\begin{tabular}{|c|c|c|c|c|}
\hline & $\ln ($ for mar pot) & $\ln (\mathrm{gdp} / \mathrm{cap})$ & $\ln ($ pop dens) & $\ln ($ urb pop dens) \\
\hline 1 & 1.000 & & & \\
\hline 2 & 0.944 & 1.000 & & \\
\hline 3 & 0.454 & 0.326 & 1.000 & \\
\hline 4 & 0.657 & 0.564 & 0.943 & 1.000 \\
\hline
\end{tabular}


Our main explanatory variables are population density (people $/ \mathrm{km}^{2}$ ) and foreign market potential. The dependent variable is GDP per capita. With equation (4) in mind, the foreign market potential (FMP) of country $r$ is defined as $F M P_{r}=\sum_{s \neq r} \frac{Y_{s}}{d_{r s}}$

where $Y_{s}$ is the GDP of country $s$ and $d_{r s}$ is the geodesic distance between the capital cities of countries $r$ and $s$. We refer to this as foreign market potential because the GDP of country $r$ is not included, see the end of section 3. Our main interest in Table 1 are the correlation coefficients. GDP per capita and foreign market potential have a strong positive correlation. The correlation between GDP per capita and density is, although positive, much weaker. The correlation coefficients between foreign market potential and the density measures also show that foreign market potential and density are clearly not perfectly correlated, which is important for the estimations (see below), where in line with the underlying theory (see sections 2 and 3 ) these 2 variables will be looked upon as measuring different aspects of economic geography.

Table 213 European regions; summary statistics, 1975-2006

\begin{tabular}{l|cccc}
\hline \hline & $\ln$ (for mar pot) & $\ln ($ gdp/cap) & $\ln$ (pop dens) & $\ln$ (work pop dens) \\
\hline Mean & 12.80 & 9.53 & 4.95 & 4.52 \\
St. error & 0.007 & 0.005 & 0.016 & 0.016 \\
Median & 12.88 & 9.59 & 4.95 & 4.49 \\
Kurtosis & -0.47 & -0.21 & 0.92 & 0.93 \\
Skewness & -0.48 & -0.34 & 0.13 & 0.10 \\
Minimum & 10.94 & 7.89 & 1.18 & 0.61 \\
Maximum & 13.88 & 10.78 & 9.09 & 8.73 \\
Count & 6,816 & 6,816 & 6,816 & 6,816 \\
\hline
\end{tabular}

correlation coefficients

\begin{tabular}{c|cccc} 
& $\ln$ (for mar pot) & $\ln$ (gdp/cap) & $\ln$ (pop dens) & $\ln$ (work pop dens) \\
1 & 1.000 & & & \\
3 & 0.636 & 1.000 & & \\
4 & 0.472 & 0.212 & 1.000 & \\
0.476 & 0.215 & 0.999 & 1.000
\end{tabular}

For mar pot $=$ foreign market potential; gdp/cap = income per capita (constant 1995 euros); pop dens = population density $\left(\right.$ people $\left./ \mathrm{km}^{2}\right)$; work pop dens = working population density (working population $/ \mathrm{km}^{2}$ ); for definitions see also Table 1 . 
Table 2 shows the summary statistics for our data set on 213 European regions. The sample period is 1975-2006. The bottom part of Table 2 indicates that for the European regions there is a positive correlation between GDP per capita and foreign market potential, but it is lower than comparable correlations with respect to countries. The same is true for the correlation between GDP per capita and density, here the correlation coefficient $(0.21)$ is actually quite low. In line with the case of the 14 countries, although there is a positive correlation between foreign market potential and density, the correlation coefficient (approximately 0.5) indicates a far from perfect correlation. $^{12}$

\section{$5 \quad$ Estimation results: comparing European regions and nations}

In this section we present our main estimation results. We thus basically set out to estimate the "density" equation (2) and the "market potential" equation (4) for our sample of 213 European regions (section 5.1) and 14 European countries (section 5.2). In doing so, we are not only interested in the possible different outcomes for these two spatial scales but also in the possible changes in the relevance of density or market potential over time. Having said this, the focus in this section is on the comparison for the period 1975-2006 on the relevance of market potential and density at two different spatial scales or aggregation levels, regions vs countries. Our data set for regions only starts in 1975 (first year with NUTS II data for EU regions). For the group of 14 countries, we can go back much further in time and this will be the topic of section 6 .

\subsection{Regional GDP, density and market potential}

Table 3 shows the panel estimation results for GDP per capita for our full sample of EU regions for 1975-2006. We include region and time fixed effects to deal with nonobserved variables that do not change over time or are constant over regions, but may affect income per capita. It would be remarkable if only the variables that are of interest in this paper would explain the bulk of GDP per capita. The inclusion of time and region fixed effects increases the explanatory power of the model. The results confirm that there is a strong positive correlation between foreign market potential and income per capita for our sample period 1975-2006. Recall, that foreign market

\footnotetext{
${ }^{12}$ Note that the sample period is different from Table 1 . This is due to data availability: NUTS data on European regions are only available from 1975 onwards.
} 
potential does not include the own-region's income. As explained in section 3, we think that the choice for foreign market potential best captures the idea of withinregion economic geography against between-region economic geography. Density is population density. ${ }^{13}$

The first two columns in Table 3 show that, in isolation, there is a positive correlation between foreign market potential and GDP per capita on the one hand and between density and GDP per capita on the other hand. Foreign market potential and density contribute positively to GDP per capita. This is also true when both variables are simultaneously included, see column 3 . The main conclusion from Table 3 is that both market potential and density have a significant positive impact on regional GDP per capita and that the impact of market potential seems relatively stronger. This suggests that at the regional level both views on economic geography matter. As to the economic significance of the baseline case (last column of Table 3): the average contribution of foreign market potential to explaining GDP per capita, calculated as the estimated coefficient multiplied by the mean of foreign market potential divided by the mean of GDP per capita (see Feenstra, 2004, p. 123), is 34.3 per cent. Similarly, the average contribution of population density is only 4.2 per cent. Thus at the regional level foreign market potential is economically more important. ${ }^{14}$

Table 3 Income per capita, market potential, and density; European regions Dependent variable is $\ln$ (GDP per capita), panel estimates (t-statistics), 1975-2006

\begin{tabular}{l|ccc}
\hline \hline Ln(foreign market potential) & 0.321 & & 0.255 \\
& $(36.7)$ & & $(23.4)$ \\
Ln(population density) & & 0.090 & 0.081 \\
& & $(37.9)$ & $(34.7)$ \\
\hline Time fixed effects & yes & yes & yes \\
Region fixed effects & yes & yes & yes \\
$\bar{R}^{2}$ & 0.782 & 0.800 & 0.815 \\
F-statistic & 521 & 580 & 625 \\
Observations & 6,816 & 6,816 & 6,816
\end{tabular}

\footnotetext{
${ }^{13} \mathrm{We}$ also used working population density as an alternative in this and subsequent estimates, as well as foreign market potential defined on population instead of GDP. The results are similar, and available upon request.

${ }^{14}$ Foreign market potential is even more important at the country level since population density is either not significant or of the wrong sign, see below.
} 
The findings in Table 3 are subject to at least two important caveats. First, both density and market potential are potentially endogenous. To correct for this, we also performed IV estimations with a region's area and distance to Brussels as instruments. The instruments are significant and have the correct sign and the IV estimations lead to similar conclusions (see Appendix B, Table 1B for these IV results). Second, we may overestimate the role of market potential or density because due to limited data availability we did not include other possible time and crosssection varying independent regional variables (like human capital), see also our discussion of equation (2) in section 3 and Overman, Rice and Venables (2008). Variables like human capital or interregional trade are not or not sufficiently available for our sample period 1975-2006 for the NUTSII regions (see also Breinlich, 2006). ${ }^{15}$

Table 4 GDP per capita, market potential, and density; European regions Dependent variable is $\ln$ (GDP per capita), t-stats in parentheses; 14-year moving observations; time and region fixed effects included

\begin{tabular}{l|ccccc}
\hline \hline end year 14-year period & 1988 & 1990 & 1992 & 1994 & 1996 \\
Ln(foreign market potential) & 0.237 & 0.239 & 0.237 & 0.234 & 0.237 \\
& $(14.0)$ & $(14.3)$ & $(14.2)$ & $(14.1)$ & $(14.5)$ \\
Ln(population density) & 0.077 & 0.078 & 0.079 & 0.080 & 0.081 \\
& $(21.4)$ & $(21.8)$ & $(22.0)$ & $(22.5)$ & $(23.1)$ \\
$\bar{R}^{2}$ & 0.804 & 0.803 & 0.803 & 0.802 & 0.802 \\
F-statistic & 391 & 391 & 389 & 389 & 387 \\
Observations & 2769 & 2769 & 2769 & 2769 & 2769 \\
\hline end year 14-year period & 1998 & 2000 & 2002 & 2004 & 2006 \\
Ln(foreign market potential) & 0.244 & 0.252 & 0.256 & 0.258 & 0.263 \\
& $(15.1)$ & $(15.5)$ & $(15.7)$ & $(15.7)$ & $(15.9)$ \\
Ln(population density) & 0.082 & 0.082 & 0.082 & 0.084 & 0.086 \\
& $(23.6)$ & $(23.6)$ & $(23.6)$ & $(24.1)$ & $(24.4)$ \\
\hline $\bar{R}^{2}$ & 0.800 & 0.798 & 0.794 & 0.792 & 0.787 \\
F-statistic & 384 & 377 & 369 & 364 & 353 \\
Observations & 2769 & 2769 & 2769 & 2769 & 2769
\end{tabular}

Table 4 repeats the exercise of Table 3, but for different time periods. Since we are also interested in the development of the market potential and density variable over time, Table 4 gives for 14-year periods the estimation results for the same specification as in the third column of Table 3 (starting with the period 1975-1988;

\footnotetext{
${ }^{15}$ For the NUTSII regions Eurostat provides education measures only from the mid-1990s onwards.
} 
the years in the column heading of Table 4 specify the end year of each of the 14-year periods). Both the value of the foreign market potential coefficient and density coefficient are stable over time (see also Figure 1 below).

All in all, the conclusion must be that for our set of 213 European regions both the market potential coefficient and the density coefficient have a positive impact on income per capita and that this impact is relatively constant across the sample period 1975-2006 with the size of the estimated market potential elasticity being consistently larger than the density elasticity.

\subsection{Country GDP, density and market potential}

Instead of regions, we now look at the corresponding set of 14 European countries for the same sample period 1975-2006. Table 5a gives the results of the panel estimations with time and country fixed effects. As in case of the European regions, we also performed IV estimations with a country's area and distance to Brussels as instruments. Additionally, we also use GDP in the year 1000 as an instrument. The instruments are significant and have the correct sign and the IV estimates lead to similar conclusions (see Appendix B, Table 2B for these IV results).

Education is included as a control variable to capture the possible impact of human capital on GDP per capita. It is measured as the average years of schooling for the population over the age of 15 using the Barro Lee data. ${ }^{16}$ Education contributes positively to GDP per capita. Our main interest is, however, with the relevance of density and market potential for GDP per capita at the country level. With respect to density we do not only look at population density but also at urban population density (defined as urban population per $\mathrm{km}^{2}$ ), based on data from McCann and Acs (2008) and the World Development Indicators online. ${ }^{17}$ The reason for this is that at the country level (as opposed to the regional or city level) a low population density can still go along with the population being concentrated in a few regions or cities to the

\footnotetext{
${ }^{16}$ This data is available on the World Bank website, see edstats - additional resources - archived data. The 5-year interval observations are interpolated for our purposes.

${ }^{17}$ Urban population density calculations are based on data from McCann and Acs (2008) for the years 1800 and 1890 (for Denmark, Norway, Sweden and Finland the Scandinavian data are used, for Austria the German data are used, and for Great Britain the England \& Wales data are used) and World Bank WDI online data for the years 1960-2007. It is an indication only as intermediate years are interpolated, but it does capture the basic differences between countries in the $19^{\text {th }}$ and $20^{\text {th }}$ century urbanization process.
} 
effect that economic interactions still mainly take place in areas with a high population density.

Table 5a GDP per capita, market potential, and density, European countries

Dependent variable is $\ln$ (income per capita), panel estimates (t-statistics), 1975-2006

\begin{tabular}{l|ccccc}
\hline \hline Ln(for. market potential) & $\begin{array}{c}0.521 \\
(3.4)\end{array}$ & & & 0.496 & 0.539 \\
& & & & $(3.4)$ & $(3.5)$ \\
Ln(population density) & & -0.821 & & -0.806 & \\
& & $(-5.5)$ & & $(-5.5)$ & \\
Ln(urban population density) & & & -0.050 & & -0.066 \\
& & & $(-1.0)$ & & $(-1.3)$ \\
\hline Average years education & 0.050 & 0.054 & 0.053 & 0.051 & 0.050 \\
& $(9.0)$ & $(10.2)$ & $(9.7)$ & $(9.6)$ & $(9.1)$ \\
Time fixed effects & yes & yes & yes & yes & yes \\
Country fixed effects & yes & yes & yes & yes & yes \\
$\bar{R}^{2}$ & 0.966 & 0.967 & 0.965 & 0.968 & 0.966 \\
F-statistic & 424 & 443 & 413 & 439 & 411 \\
Observations & 448 & 448 & 448 & 448 & 448 \\
\hline \hline
\end{tabular}

b. different sub-periods, country*

\begin{tabular}{l|ccccc}
\hline End year 14-year period & 1988 & 1990 & 1992 & 1994 & 1996 \\
Ln(foreign market potential) & 0.740 & 0.893 & 1.023 & 1.088 & 1.163 \\
& $(5.0)$ & $(5.4)$ & $(5.6)$ & $(5.9)$ & $(5.6)$ \\
Ln(population density) & -0.740 & -0.542 & -0.985 & -1.243 & -1.487 \\
& $(-3.4)$ & $(-2.3)$ & $(-3.9)$ & $(-4.5)$ & $(-5.0)$ \\
$\bar{R}^{2}$ & 0.988 & 0.987 & 0.982 & 0.976 & 0.970 \\
F-statistic & 682 & 607 & 450 & 333 & 267 \\
Observations & 182 & 182 & 182 & 182 & 182 \\
\hline end year 14-year period & 1998 & 2000 & 2002 & 2004 & 2006 \\
Ln(foreign market potential) & 1.044 & 0.850 & 0.805 & 0.594 & 0.403 \\
& $(4.8)$ & $(4.0)$ & $(4.0)$ & $(3.2)$ & $(2.4)$ \\
Ln(population density) & -1.128 & -0.309 & 0.082 & 0.045 & -0.404 \\
& $(-3.4)$ & $(-0.8)$ & $(0.2)$ & $(0.1)$ & $(-1.2)$ \\
\hline $\bar{R}^{2}$ & 0.965 & 0.964 & 0.970 & 0.972 & 0.973 \\
F-statistic & 228 & 223 & 265 & 286 & 297 \\
Observations & 182 & 182 & 182 & 182 & 182
\end{tabular}

*Time and country fixed effects are included as well as avg. years of education 
For both measures of density shown in Table 5a, the impact on GDP is either not significant (urban population density) or significantly negative (population density). This is a main difference with the estimation results at the regional level in Table 3 and this result also holds when we use alternative measures, such as market potential in terms of population (instead of GDP). ${ }^{18}$ Again panel estimates are preferred as these allow us to incorporate country- and time fixed effects.

Figure 1 Estimated elasticities; countries and regions, panel estimates, 1975-2006*

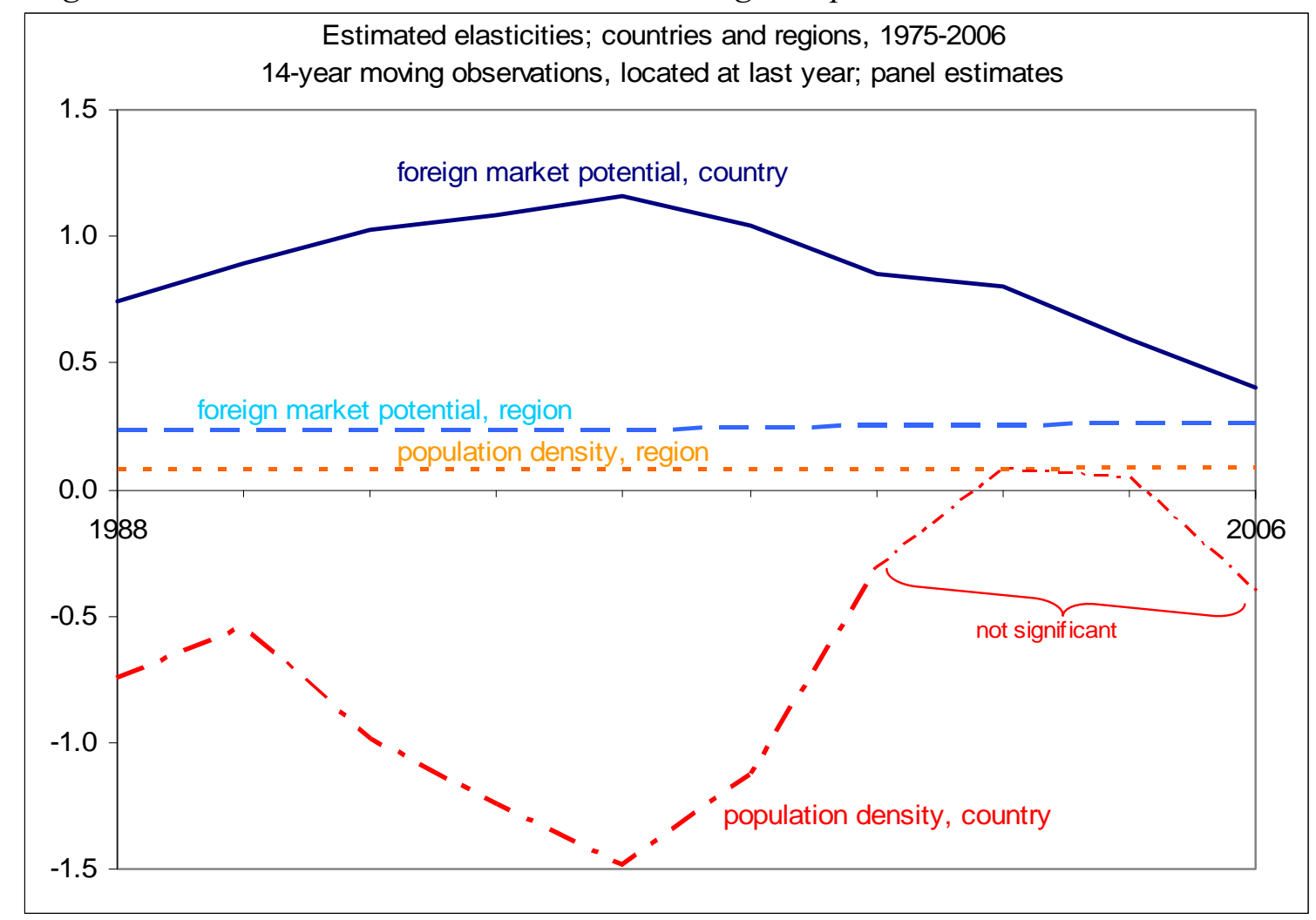

*Time and country fixed effects are included as well as average years of schooling.

As a mirror image to Table 4, Table $5 \mathrm{~b}$ shows the results for the 14 European countries for the sub-samples of 14 year periods (the years in the heading of the columns refers to the last year in each 14 year period). In table $5 \mathrm{~b}$ the market potential coefficient is always significantly positive and steadily increasing until 1996 and decreases afterwards, whereas density is much more volatile and not always significant. This is thus a clear difference compared to the similar regional estimations. Figure 1 shows the development over time of estimated coefficients

\footnotetext{
${ }^{18}$ Note that the $\mathrm{R}^{2}$ is rather high which, given the long time period involved, might be due to a positive time trend in the variables concerned. Panel estimates in first differences - implying the inclusion of time fixed effects only - confirm the panel estimates described in the main text, see Table $3 \mathrm{~B}$ in appendix B.
} 
(interpolation connects the point estimates) for both foreign market potential and population density. The figure summarizes not only the main findings for the period 1975-2006 at the country level with respect to the (relative) importance of market potential and population density but does the same for the region level (using the regional estimations from Table 4). Bear in mind from the discussion in sections 2 and 3 that foreign market potential is our approximation of the role of economic geography in the sense of spatial interdependencies between locations, whereas (population) density does the same for the role of the economic geography of the location itself.

Based on Figure 1, the following conclusions can be reached. First, market potential has a significantly positive impact on GDP per capita at both the country and regional level, but consistently more so at the country level, although the difference becomes smaller over time. Second, population density consistently has a positive impact on GDP per capita at the regional level, but this is no longer true at the country level. These findings, as illustrated by Figure 1, thus seem to indicate that spatial interdependencies (in casu market potential) matter more on a higher level of spatial aggregation (confirming the suggestions made by, for instance, Combes, Duranton and Overman, 2005, see section 2) whereas location-specific economic geography (in casu (urban) population density) matters primarily at a lower level of spatial aggregation.

As an illustration that our specification with country- and time fixed effects and the inclusion of foreign market potential adequately deals with spatial autocorrelation issues, Figure 2 provides the evolution over time of Moran's I of the estimation errors associated with the baseline estimations (column 3 in Table 3 and column 4 in Table 5a). ${ }^{19}$ This simple measure of spatial autocorrelation is low and never statistically significant. ${ }^{20}$

${ }^{19}$ Moran's I is defined as: $I=\frac{N}{\sum_{r} \sum_{s} w_{r s}} \frac{\sum_{r} \sum_{s} w_{r s} z_{r} z_{s}}{\sum_{r} z_{r}^{2}}$, where $r$ and $s$ are region-indices; $w_{r s}$ is a measure of contiguity of regions $r$ en $s$ (our's is proportional to the inverse of the distance between them); and $z_{r}$ is a measure of relative economic activity. Let $x_{r}$ be some measure of economic activity in region $r$, where we use (i) $\ln$ (gdp per capita), (ii) growth rate gdp per capita, or (iii) gdp $/ \mathrm{km}^{2}$, then the measure of relative economic activity in region $\mathrm{r}$ used is: $z_{r}=x_{r}-\bar{x}$.

${ }^{20}$ The Moran's I for the country errors fluctuates more than the one for the region errors as it is based on fewer observations. We also calculated the correlation coefficients for the whole period per spatial country and region pairing and graphed this relative to the log of their bilateral distances to find no 
Figure 2 Moran's I for baseline case error terms

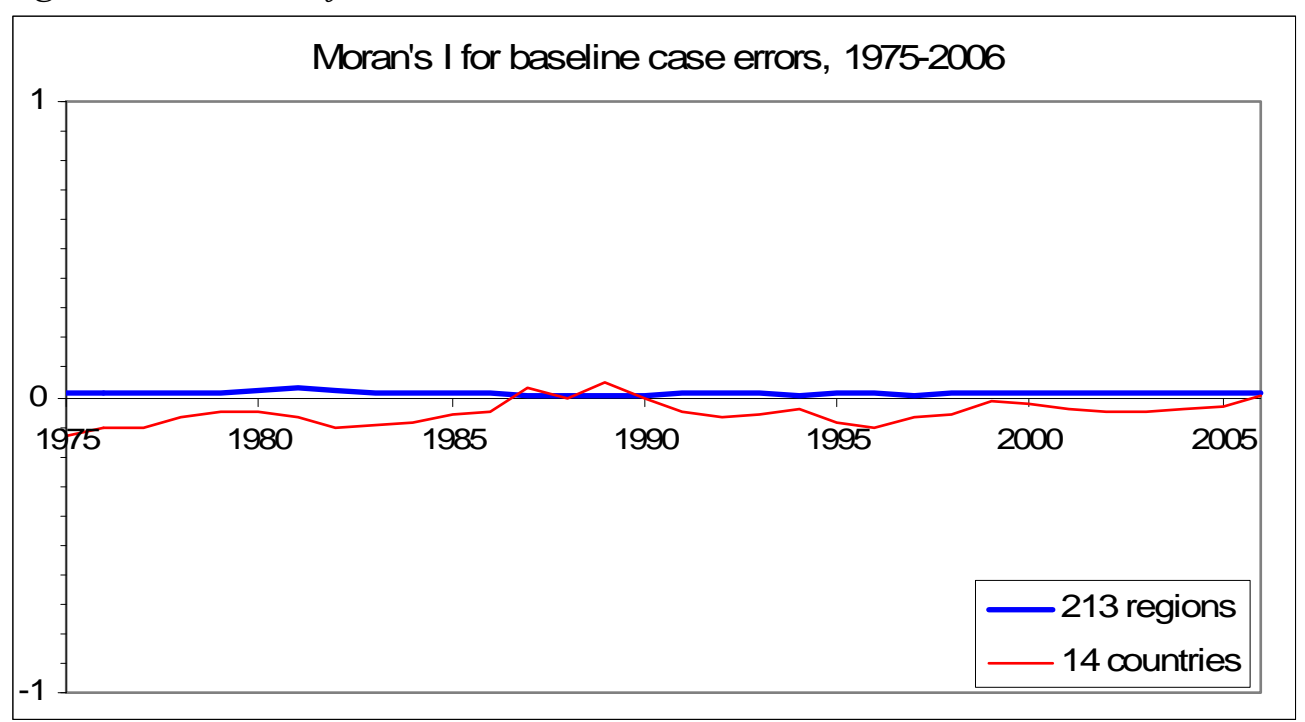

Apart from the level of spatial aggregation, we are also interested in the behavior of our two between-location and within-location economic variables, market potential and (population) density, over time. The sample period used so far, 19752006, thus allows us to do so for a 30 year period. For countries, we can, however, go back much further in time. This is the topic of the next section.

\section{Market potential and density at the country level 1870-2006.}

Table 6 gives the panel estimates for the 14 European countries for the whole sample period 1870-2006 (apart from the sample period, the specification is similar to the one underlying Table 5a). Again, we find that the market potential coefficient is significantly positive and, as opposed to Table 5a, that the density coefficient is also significantly positive for this longer sample period. ${ }^{21}$ In line with our discussion of Table 5a, at the country level we also replaced population density with urban population density, and also in that case the market potential and density coefficient remain significantly positive (see third column Table 6 ). ${ }^{22}$

remaining spatial dimension of the error terms (a meta regression of these data - which is available upon request - confirmed this).

${ }^{21}$ As in the case of European countries for the period 1975-2006, we also performed IV estimations with a country's area, distance to Brussels and GDP in the year 1000, as instruments. The instruments are significant and have the correct sign and the IV estimates lead to similar conclusions (results are available upon request).

${ }^{22}$ Urbanization data are from McCann and Acs (2008) for the initial period and World Development Indicators from 1960 onwards; the period 1870-1959 is based on interpolations of the percent of urban 
Table 6 GDP per capita, market potential, and density; 14 countries, 1870-2006 Dependent variable is $\ln$ (GDP per capita), panel estimates (t-statistics)

\begin{tabular}{l|cccc}
\hline \hline Ln(for. market pot. Gdp) & $\begin{array}{c}0.405 \\
(5.8)\end{array}$ & $\begin{array}{c}0.353 \\
(5.0)\end{array}$ & 0.338 \\
Ln(population density) & $\begin{array}{c}0.242 \\
(6.3)\end{array}$ & & $\begin{array}{c}0.216 \\
(5.6)\end{array}$ & \\
Ln(urban population density) & & & 0.392 \\
& & & & $(25.4)$ \\
\hline Time fixed effects & Yes & yes & yes & Yes \\
Country fixed effects & Yes & yes & yes & Yes \\
$\bar{R}^{2}$ & 0.964 & 0.963 & 0.963 & 0.973 \\
F-statistic & 1,227 & 1,231 & 1,235 & 1,665 \\
Observations & 1,918 & 1,918 & 1,918 & 1,918
\end{tabular}

Note that the period 1870-2006 includes the economic crisis of the 1930s, two world wars as well as 2 periods (following WWI and WWII) of limited international trade and factor mobility. Given these and other large shocks, it is instructive to take a closer look at separate sub-periods and maybe not focus too much on the estimation results for the whole (rather heterogeneous) sample period. Table 7 and the corresponding Figure 3 below show the development of both foreign market potential and density elasticities for sub-sample estimations with 32-year sub-periods.

The foreign market potential is positive except in the inter-bellum and the period including WWII, which is also the period that includes the Great Depression and protectionist measures that went hand in hand with the economic downturn. The slow return to more liberalized trade after WWII war is reflected in the foreign market potential variable that is insignificant in the mid-period of 1870-2006, but slowly becomes positive and significant when 32 year period estimates fully start to cover the post-WWII world (see estimation result for 32-year period ending in 1976 in Table 7). 
Table 7 GDP per capita, market potential, and density, 14 countries, 1870-2006 Dependent variable is $\ln$ (GDP per capita), t-statistics in parentheses

Panel estimates with time and country fixed effects

\begin{tabular}{|c|c|c|c|c|c|c|}
\hline end year 32-year period & 1901 & 1906 & 1911 & 1916 & 1921 & 1926 \\
\hline $\operatorname{Ln}($ foreign market potential) & $\begin{array}{c}0.444 \\
(5.9)\end{array}$ & $\begin{array}{c}0.389 \\
(4.9)\end{array}$ & $\begin{array}{c}0.456 \\
(5.8)\end{array}$ & $\begin{array}{c}0.482 \\
(5.7)\end{array}$ & $\begin{array}{c}0.139 \\
(1.4)\end{array}$ & $\begin{array}{c}0.209 \\
(2.3)\end{array}$ \\
\hline Ln(population density) & $\begin{array}{r}0.082 \\
(0.9)\end{array}$ & $\begin{array}{r}0.219 \\
(2.6)\end{array}$ & $\begin{array}{c}0.235 \\
(2.7)\end{array}$ & $\begin{array}{c}-0.001 \\
(0.0)\end{array}$ & $\begin{array}{c}0.370 \\
(3.4)\end{array}$ & $\begin{array}{c}0.593 \\
(5.6)\end{array}$ \\
\hline $\bar{R}^{2}$ & 0.981 & 0.982 & 0.980 & 0.975 & 0.955 & 0.952 \\
\hline F-statistic & 1,089 & 1,148 & 1,028 & 825 & 457 & 426 \\
\hline Observations & 448 & 448 & 448 & 448 & 448 & 448 \\
\hline end year 32-year period & 1931 & 1936 & 1941 & 1946 & 1951 & 1956 \\
\hline \multirow[t]{2}{*}{$\operatorname{Ln}($ foreign market potential) } & 0.280 & 0.353 & 0.370 & -0.019 & 0.088 & 0.071 \\
\hline & $(3.4)$ & $(4.1)$ & $(3.9)$ & $(-0.1)$ & $(0.7)$ & $(0.6)$ \\
\hline \multirow[t]{2}{*}{ Ln(population density) } & 0.748 & 0.802 & 0.367 & 0.301 & 0.876 & 1.193 \\
\hline & $(7.5)$ & $(7.7)$ & $(2.9)$ & $(1.5)$ & $(4.0)$ & $(5.7)$ \\
\hline $\bar{R}^{2}$ & 0.956 & 0.951 & 0.930 & 0.859 & 0.847 & 0.872 \\
\hline F-statistic & 465 & 415 & 284 & 131 & 119 & 146 \\
\hline Observations & 448 & 448 & 448 & 448 & 448 & 448 \\
\hline end year 32-year period & 1961 & 1966 & 1971 & 1976 & 1981 & 1986 \\
\hline \multirow[t]{2}{*}{$\operatorname{Ln}($ foreign market potential) } & 0.019 & 0.062 & 0.072 & 0.539 & 0.782 & 0.823 \\
\hline & $(0.2)$ & $(0.7)$ & $(0.7)$ & $(5.8)$ & $(10.6)$ & $(11.1)$ \\
\hline \multirow[t]{2}{*}{ Ln(population density) } & 1.137 & 1.324 & 1.082 & -0.398 & -0.317 & -0.002 \\
\hline & $(5.6)$ & $(6.7)$ & $(5.2)$ & $(-1.9)$ & $(-2.0)$ & $(0.0)$ \\
\hline \multirow{3}{*}{$\begin{array}{l}\bar{R}^{2} \\
\text { F-statistic } \\
\text { Observations }\end{array}$} & 0.899 & 0.919 & 0.923 & 0.936 & 0.962 & 0.962 \\
\hline & 191 & 244 & 255 & 312 & 534 & 541 \\
\hline & 448 & 448 & 448 & 448 & 448 & 448 \\
\hline \multirow{3}{*}{$\begin{array}{l}\text { end year 32-year period } \\
\text { Ln(foreign market potential) }\end{array}$} & 1991 & 1996 & 2001 & 2006 & & All \\
\hline & 0.854 & 0.875 & 0.926 & 0.937 & & 0.405 \\
\hline & $(12.4)$ & (12.4) & $(13.0)$ & $(12.6)$ & & $(5.8)$ \\
\hline \multirow[t]{2}{*}{ Ln(population density) } & 0.306 & 0.078 & -0.172 & -0.720 & & 0.242 \\
\hline & $(2.0)$ & $(0.5)$ & $(-1.1)$ & $(-4.5)$ & & $(6.3)$ \\
\hline $\bar{R}^{2}$ & 0.961 & 0.960 & 0.958 & 0.962 & & 0.964 \\
\hline F-statistic & 523 & 506 & 488 & 535 & & 1,227 \\
\hline Observations & 448 & 448 & 448 & 448 & & 1,918 \\
\hline
\end{tabular}


Figure 3 Estimated elasticities, countries, 1870-2006
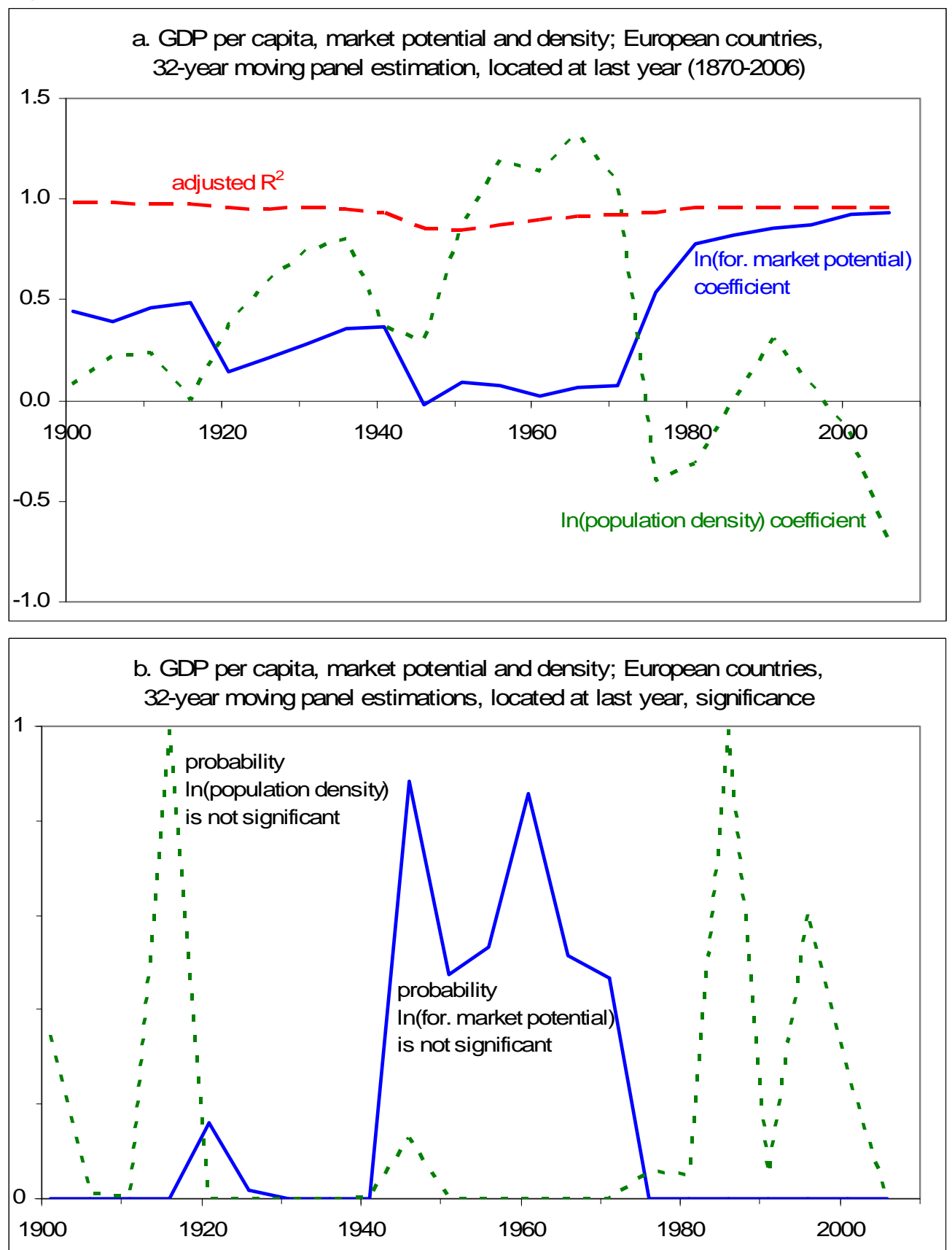

The development over time is most readily seen from Figure 3. In this sense the foreign market potential variable seems to have a close relation with the general trend of globalization: the first wave of globalization ending around WW I and the second wave staring after WW II. This leads to the conclusion that the more recent period and the period ending in 1914 are alike in this sense. The mid-period seems to be the exception. When it comes to the significance of density, the estimation results in Table 7 display a much more erratic picture. As Figure $3 \mathrm{~b}$ shows, density is mostly (but not always) significant and with the expected positive sign for the density 
coefficient in the period before and just after WWII but from thereon the density coefficient, in line with Table $5 \mathrm{~b}$ and Figure 1, largely becomes insignificant.

\section{Conclusions}

Two approaches dominate recent research in economics on the uneven spatial distribution of economic activity: urban economics and new economic geography (NEG). A main difference between the two approaches is that urban economics neglects spatial interdependencies between regions whereas NEG stresses the relevance of spatial linkages between regions. There is not much systematic evidence yet on the relevance of these (complementary) views on the role of economic geography for different aggregation levels and time periods. This paper tries to fill this gap. In particular, for our data set with 14 European countries and 213 regions we investigate whether the impact on GDP per capita of our two approximations of the within-location and between-location geography view (market potential and density, respectively) depends on the level of spatial aggregation (country vs region) or varies over time. By and large, we find that market potential is more relevant at the country level, whereas density is more relevant at the regional level. Our findings support the idea that spatial interdependencies are more relevant at higher levels of spatial aggregation. 


\section{Appendix A Derivation of wage equations (1) and (3)}

Derivation of equation (1)

The set-up is straightforward. Consider a firm $j$ in region $r$ that uses labor $l$ and a (composite) input $k$ in its production process to produce $y$ :

$y_{j}=A_{j}\left(s_{j} l_{j}\right)^{\mu} k_{j}^{1-\mu}$; where $A_{j}=$ technology (Hicks-Neutral); $\mu=$ share of labor in the production process; $s_{j}=$ labor productivity variable

The profits of this firm, that exports to all regions $s$, are:

$\pi_{j}=\sum_{s} p_{j s} y_{j s}-w_{j} l_{j}-q_{j} k_{j}=p_{j} y_{j}-w_{j} l_{j}-q_{j} k_{j}$, where $p_{j}=\sum_{s} p_{j s} \frac{y_{j s}}{y_{j}}$

where $w_{r}=$ wage in region $r ; p_{j}=$ price of $\operatorname{good} j ; q_{j}=$ price of (composite of) other inputs. The first order conditions are:

$w_{j}=\mu p_{j} A_{j} s_{j}^{\mu}\left(\frac{k_{j}}{l_{j}}\right)^{1-\mu}, q_{j}=(1-\mu) p_{j} A_{j} s_{j}^{\mu}\left(\frac{k_{j}}{l_{j}}\right)^{-\mu}$

Substituting the second equation into the first gives the (individual) firm wage equation:

$w_{j}=\mu(1-\mu)^{(1-\mu) / \mu} s_{j}\left(\frac{p_{j} A_{j}}{q_{j}^{1-\mu}}\right)^{1-\mu}$

Summing over all firms $n_{r}$ in region $r$ gives equation (1) in the text:

$$
w_{r}=\frac{\mu(1-\mu)^{(1-\mu) / \mu}}{n_{r}} \sum_{j \in n_{r}} s_{j}\left(\frac{p_{j} A_{j}}{q_{j}^{1-\mu}}\right)^{1-\mu}
$$

Derivation of equation (3)

It is by now well-known that operating profits of a firm in region $r$ operating in $s-$ needed to cover the fixed costs of production - in a monopolistic competition setting can be formulated as follows:

$\pi_{r s}=\left(p_{r}-m c_{r}\right) \tau_{r s} x_{r s}=m c_{r} \frac{\tau_{r s} x_{r s}}{\sigma-1}$,

where $p_{r}=$ is the mill-price of the product of a firm located in $r ; m c_{r}=$ marginal costs of this firm; $\tau_{r s}=$ the iceberg transportation costs between regions $r$ and $s ; x_{r s}=$ the quantity that a firm located in $r$ sells in $s$ (it is multiplied by $\tau_{r s}$; because a part of the product melts during transportation); $\sigma=$ elasticity of substitution between varieties. The second equality follows from mark-up pricing over $m c$.

Assuming a CES-utility function, utility maximization gives:

$x_{r s}=\left(p_{r} \tau_{r s}\right)^{-\sigma} \delta_{s} Y_{s} P_{s}^{\sigma-1}$, where $P_{s}=\left(\sum_{r} n_{r}\left(p_{r} \tau_{r s}\right)^{-(\sigma-1)}\right)^{-1 /(\sigma-1)}$, and $\delta_{\mathrm{s}}=$ the share of the good in income of $s$.

Total profits - including fixed costs, $\mathrm{F}_{\mathrm{r}}$ - can be derived as the sum over profits in all destination regions. Using the equations above and the definition of operating profits, total profits are:

$\Pi_{r}=\sum_{s} \pi_{r s}-F_{r}=\sigma^{-\sigma} /(\sigma-1)^{-(\sigma-1)} m c_{r}^{-(\sigma-1)} R M P_{r}-F_{r}$,

where $R M P_{r}=\sum_{s} \phi_{r s} \delta Y_{s}^{\sigma-1} P_{s}^{\sigma-1}$

Assuming zero total profits we have, after rewriting: 
$m c_{r}=\left(\frac{\sigma^{-\sigma} /(\sigma-1)^{-(\sigma-1)} R M P_{r}}{F_{r}}\right)^{1 /(\sigma-1)}$

We are now very close to a wage equation comparable to equation (1); we only have to model marginal costs. We can for example assume that the production process uses only labor, that is, marginal costs are for example, $m c_{r}=a w_{r}^{\alpha}$, substituting this in the equation above gives equation (3) in the main text: ${ }^{23}$

$\ln w_{r}=\frac{1}{\sigma} \ln R M P_{r}-\frac{1}{\sigma} \ln \left(\frac{a}{c}\right)$, where $c=\sigma^{-\sigma} /(\sigma-1)^{-(\sigma-1)}$

\section{Appendix B Sensitivity analyses}

Table $1 B$ GDP per capita, market potential, and density, European regions

Dependent variable is $\ln$ (income per capita), t-statistics in parentheses, 1975-2006

\begin{tabular}{l|ccc}
\hline \multicolumn{2}{l}{ Two stage least squares; area and ln distance to Brussels as instrument } \\
Ln(for. Market potential) & 0.498 & & \\
& $(30.6)$ & 0.126 & $(18.0)$ \\
Ln(population density) & & $(27.3)$ & 0.040 \\
& & yes & $(6.0)$ \\
\hline Time fixed effects & yes & yes & Yes \\
Region fixed effects & yes & 0.793 & yes \\
$\bar{R}^{2}$ & 0.774 & 547 & 0.803 \\
F-statistic & 508 & 6,816 & 571 \\
Observations & 6,816 & & 6,816 \\
\hline \hline
\end{tabular}

First stage results

\begin{tabular}{l|cc} 
Dependent variable & $\operatorname{Ln}$ (population density) & $\ln$ (for. market pot. gdp) \\
\hline $\ln$ (distance to Brussels) & -0.598 & -0.389 \\
& $(-21.4)$ & $(-80.7)$ \\
area* & -27.10 & -1.86 \\
& $(-40.9)$ & $(-16.3)$ \\
\hline Time fixed effects & yes & yes \\
Country fixed effects & yes & yes \\
$\bar{R}^{2}$ & 0.567 & 0.929 \\
F-statistic & 187 & 1,867 \\
Observations & 6,816 & 6,816
\end{tabular}

* area coefficient $\times$ one million

Note that the instruments are significant and have the expected negative sign

${ }^{23}$ Using other inputs is straightforward and adds other costs factors. 
Table 2B Income per capita, market potential, and density, European countries Dependent variable is $\ln$ (income per capita), t-statistics in parentheses, 1975-2006

\begin{tabular}{l|ccc}
\hline \hline $\begin{array}{l}\text { Two stage least squares; area, ln distance to Brussels, and ln GDP in the year } 1000 \\
\text { as instrument } \\
\ln \text { (for. market potential) }\end{array}$ & $\begin{array}{c}0.161 \\
(7.6)\end{array}$ & 0.006 & 0.413 \\
& & $(0.7)$ & $(15.2)$ \\
$\ln$ (population density) & & -0.112 \\
& yes & $(-11.5)$ \\
Time fixed effects & no & no & yes \\
Country fixed effects & 0.606 & 0.476 & no \\
$\bar{R}^{2}$ & 39 & 27 & 0.771 \\
F-statistic & 448 & 448 & 71 \\
Observations & & & 448 \\
\hline \hline
\end{tabular}

\begin{tabular}{|c|c|c|}
\hline Dependent variable & Ln(population density) & $\ln ($ for. market potential) \\
\hline $\ln$ (distance to Brussels) & $\begin{array}{l}-0.406 \\
(-21.6)\end{array}$ & $\begin{array}{l}-0.306 \\
(-34.7)\end{array}$ \\
\hline area* & $\begin{array}{c}-3.83 \\
(-34.4)\end{array}$ & $\begin{array}{c}-0.69 \\
(-13.1)\end{array}$ \\
\hline $\ln \left(\mathrm{GDP}_{1000}\right)$ & $\begin{array}{l}0.534 \\
(41.2)\end{array}$ & $\begin{array}{c}0.023 \\
(3.8)\end{array}$ \\
\hline Time fixed effects & yes & yes \\
\hline Country fixed effects & no & no \\
\hline $\bar{R}^{2}$ & 0.898 & 0.868 \\
\hline F-statistic & 219 & 165 \\
\hline Observations & 448 & 448 \\
\hline
\end{tabular}

Note, that the instruments are significant; distance to Brussels and Area have, as in the case for regions, the expected negative sign, whereas the additional instrument GDP in the year 1000 has a positive sign. 
Table 3B GDP per capita, market potential, and density, European countries

Dependent variable is dln(income per capita), panel estimates (t-statistics), 1975-2006

\begin{tabular}{|c|c|c|c|}
\hline dln(for. market pot. gdp) & $\begin{array}{c}0.734 \\
(8.8)\end{array}$ & & $\begin{array}{c}0.722 \\
(8.7)\end{array}$ \\
\hline dln(population density) & & $\begin{array}{c}-0.766 \\
(-2.9)\end{array}$ & $\begin{array}{c}-0.656 \\
(-2.7)\end{array}$ \\
\hline Time fixed effects & yes & yes & yes \\
\hline Country fixed effects & no & no & no \\
\hline $\bar{R}^{2}$ & 0.292 & 0.181 & 0.302 \\
\hline F-statistic & 12.5 & 7.2 & 12.4 \\
\hline Observations & 448 & 448 & 448 \\
\hline
\end{tabular}

\section{References}

Baldwin, R., R. Forslid, Ph. Martin, G.I.P. Ottaviano, and F. Robert-Nicoud (2003), Economic Geography and Public Policy, Princeton University Press, Princeton.

Berry, C. and E.L. Glaeser (2005), "The divergence of human capital levels across cities," Papers in Regional Science 84(3): 407-444.

Bosker, M., and H. Garretsen (2008), "Trade costs, market access and economic geography: why the empirical specification of trade costs matters." mimeo, Utrecht University.

Brakman, S., H. Garretsen, and C. van Marrewijk (2009), The New Introduction to Geographical Economics, Cambridge University Press.

Breinlich, H. (2006), "The spatial income structure in the European Union - what role for economic geography?," Journal of Economic Geography 6: 593-617.

Brülhart, M, and F. Sbergami (2009) "Agglomeration and Growth: Cross-Country Evidence", ,Journal of Urban Economics, Vol. 65: 48-63.

Brülhart, M, and P. Koenig (2006) "New Economic Geography Meets Comecon: Regional Wages and Industry Location in Central Europe", Economics of Transition, Vol. 14, pp. 245-267.

Ciccone, A. (2002), “Agglomeration effects in Europe," European Economic Review 46: 213-237.

Ciccone, A., and R.E. Hall (1996), "Productivity and the density of economic activity," American Economic Review 86: 54-70.

Combes, P-P., G. Duranton, and H. Overman (2005), "Agglomeration and the adjustment of the spatial economy," Papers in Regional Science 84(3): 311-349. 
Combes, P-P., G. Duranton, and L. Gobillon (2008), "Spatial wage disparities: sorting matters!," Journal of Urban Economics, Journal of Urban Economics, Vol. 63, pp. $723-742$

Combes, P-P., G. Duranton, H.G. Overman, and A.J. Venables (2006), Economic linkages across space, Office of the Deputy Prime Minister, London.

Combes, P-P., Th. Mayer, and J-F. Thisse (2008), Economic Geography: the Integration of Regions and Nations, Princeton University Press, Princeton.

Duranton, G., and H.G. Overman (2005), "Testing for localization using microgeographic data," Review of Economic Studies, 72(4): 1077-1106.

Duranton, G., and D. Puga (2004), "Micro-foundations of urban agglomeration economies," in: J.V. Henderson and J-F. Thisse (eds)., Handbook of Regional and Urban Economics: Cities and Geography, Vol.4, North-Holland, Amsterdam: 2063-2118.

Eaton, J. and Z. Eckstein (1997), Cities and Growth: theory and evidence from France and Japan, Regional Science and Urban Economics, Vol. 27, pp. 443-474.

Federal Reserve Bank of New York, (2005), "Urban dynamics in New York city," Economic Policy Review 11(2).

Feenstra, R.C. (2004), Advanced International Trade: Theory and Evidence, Princeton University Press, Princeton N.J.

Fingleton, B. (2006), “The new economic geography versus urban economics: an evaluation using local wage rates in Great Britain," Oxford Economic Papers 58: 501-530.

Fujita, M., and J-F. Thisse (2002), Economics of Agglomeration: cities, regions, and international trade, MIT press, Cambridge Mass.

Fujita, M., and T. Mori (2005), "Frontiers of the new economic geography," Papers in Regional Science 84(3): 377-407.

Glaeser, E.L. (2008), Cities, Agglomeration and Spatial Equilibrium, Oxford University Press, Oxford.

Hanson, G.H. (2005), "Market potential, increasing returns, and geographic concentration," Journal of International Economics 67(1): 1-24.

Harris, C. (1954), "The market as a factor in the localization of industry in the United States," Annals of the Association of American Geographers 64: 315-348. 
Head, K., and Th. Mayer (2004a), "The empirics of agglomeration and trade," in V. Henderson and J-F. Thisse (eds.), Handbook of Regional and Urban Economics, Vol. IV, North Holland, Amsterdam: 2609-2665.

Henderson, J.V. (1974), “The sizes and types of cities," American Economic Review 64: 640-656.

Krugman, P.R. (1991), "Increasing returns and economic geography," Journal of Political Economy 99: 483-499.

Leamer, E., and J. Levinsohn (1995), "International trade theory: the evidence," in: G.M. Grossman and K. Rogoff (eds.), Handbook of International Economics, Vol 3, North-Holland, Amsterdam.

Maddison, A. (2008), http://www.ggdc.net/maddison/Historical_Statistics/horizontalfile 03-2009.xls.

Martin, R. (1999), “The new 'geographical turn' in economics: some critical reflections," Cambridge Journal of Economics 23: 65-91.

Martin, R. (2008), “The 'new economic geography': credible models of the economic landscape,?" in: R. Lee, A. Leyshon, L. McDowell, and P. Sunley (eds.), A Compendium of Economic Geography, Sage Publications, London and New York.

McCann, P., and Z. Acs (2008), "Globalisation: countries, cities, and multinationals," paper presented at the IHS conference "Are cities more important than countries?," Erasmus University, Rotterdam, 30 and 31 October 2008.

Moretti, E. (2004), "Human capital externalities in cities," in: J.V. Henderson and J-F. Thisse (eds), Handbook of Regional and Urban Economics, Vol. 4, North-Holland, Amsterdam: 2243-2292.

Ottaviano, G.I.P., and J-F. Thisse (2004), “Agglomeration and economic geography," in: J.V.Henderson and J-F. Thisse (eds.), Handbook of Regional and Urban Economics, Vol. 4, Elsevier North-Holland, Amsterdam: 2563-2608.

Overman, H.G., P. Rice, and A.J. Venables (2008), "Economic linkages across space," CEPR Discussion Paper, no. 6786, London.

Partridge, M. D., D. S. Rickman, K. Ali and M. R. Olfert (2008), Lost in Space: Population Growth in American Hinterlands and small cities, Journal of Economic Geography, Vol. 8, pp. 727-757.

Partridge, Mark D., D. S. Rickman, K. Ali and M. R. Olfert (2009), Agglomeration Spillovers and Wage and Housing Cost Gradients Across the Urban Hierarchy, Journal of International Economics, Forthcoming. 
Redding, S., and A.J. Venables (2004), "Economic geography and international inequality," Journal of International Economics 62(1): 53-82.

Rosenthal, S.S., and W.C. Strange (2004), "Evidence on the nature and sources of agglomeration economics," in: J.V. Henderson and J-F. Thisse (eds), Handbook of Regional and Urban economics, Elsevier North-Holland, Amsterdam. 


\section{CESifo Working Paper Series}

for full list see www.cesifo-group.org/wp

(address: Poschingerstr. 5, 81679 Munich, Germany, office@cesifo.de)

2593 Paolo M. Panteghini, On the Equivalence between Labor and Consumption Taxation, March 2009

2594 Bruno S. Frey, Economists in the PITS?, March 2009

2595 Natalie Chen and Dennis Novy, International Trade Integration: A Disaggregated Approach, March 2009

2596 Frédérique Bec and Christian Gollier, Term Structure and Cyclicity of Value-at-Risk: Consequences for the Solvency Capital Requirement, March 2009

2597 Carsten Eckel, International Trade and Retailing, March 2009

2598 Gianni De Nicolò and Iryna Ivaschenko, Global Liquidity, Risk Premiums and Growth Opportunities, March 2009

2599 Jay Pil Choi and Heiko Gerlach, International Antitrust Enforcement and Multi-Market Contact, March 2009

2600 Massimo Bordignon and Guido Tabellini, Moderating Political Extremism: Single Round vs Runoff Elections under Plurality Rule, April 2009

2601 Ana B. Ania and Andreas Wagener, The Open Method of Coordination (OMC) as an Evolutionary Learning Process, April 2009

2602 Simon Gächter, Daniele Nosenzo, Elke Renner and Martin Sefton, Sequential versus Simultaneous Contributions to Public Goods: Experimental Evidence, April 2009

2603 Philippe Jehiel and Andrew Lilico, Smoking Today and Stopping Tomorrow: A Limited Foresight Perspective, April 2009

2604 Andreas Knabe, Steffen Rätzel, Ronnie Schöb and Joachim Weimann, Dissatisfied with Life, but Having a Good Day: Time-Use and Well-Being of the Unemployed, April 2009

2605 David Bartolini and Raffaella Santolini, Fiscal Rules and the Opportunistic Behaviour of the Incumbent Politician: Evidence from Italian Municipalities, April 2009

2606 Erkki Koskela and Jan König, Can Profit Sharing Lower Flexible Outsourcing? A Note, April 2009

2607 Michel Beine, Frédéric Docquier and Çağlar Özden, Diasporas, April 2009

2608 Gerd Ronning and Hans Schneeweiss, Panel Regression with Random Noise, April 2009 
2609 Adam S. Booij, Bernard M.S. van Praag and Gijs van de Kuilen, A Parametric Analysis of Prospect Theory's Functionals for the General Population, April 2009

2610 Jeffrey R. Brown, Julia Lynn Coronado and Don Fullerton, Is Social Security Part of the Social Safety Net?, April 2009

2611 Ali Bayar and Bram Smeets, Economic, Political and Institutional Determinants of Budget Deficits in the European Union, April 2009

2612 Balázs Égert, The Impact of Monetary and Commodity Fundamentals, Macro News and Central Bank Communication on the Exchange Rate: Evidence from South Africa, April 2009

2613 Michael Melvin, Christian Saborowski, Michael Sager and Mark P. Taylor, Bank of England Interest Rate Announcements and the Foreign Exchange Market, April 2009

2614 Marie-Louise Leroux, Pierre Pestieau and Gregory Ponthiere, Should we Subsidize Longevity?, April 2009

2615 Ronald MacDonald, Lukas Menkhoff and Rafael R. Rebitzky, Exchange Rate Forecasters' Performance: Evidence of Skill?, April 2009

2616 Frederick van der Ploeg and Steven Poelhekke, The Volatility Curse: Revisiting the Paradox of Plenty, April 2009

2617 Axel Dreher, Peter Nunnenkamp, Hannes Öhler and Johannes Weisser, Acting Autonomously or Mimicking the State and Peers? A Panel Tobit Analysis of Financial Dependence and Aid Allocation by Swiss NGOs, April 2009

2618 Guglielmo Maria Caporale, Roman Matousek and Chris Stewart, Rating Assignments: Lessons from International Banks, April 2009

2619 Paul Belleflamme and Martin Peitz, Asymmetric Information and Overinvestment in Quality, April 2009

2620 Thomas Dohmen, Armin Falk, David Huffman and Uwe Sunde, Are Risk Aversion and Impatience Related to Cognitive Ability?, April 2009

2621 Yin-Wong Cheung and Xingwang Qian, The Empirics of China's Outward Direct Investment, April 2009

2622 Frédérique Bec and Christian Gollier, Assets Returns Volatility and Investment Horizon: The French Case, April 2009

2623 Ronnie Schöb and Marcel Thum, Asymmetric Information Renders Minimum Wages Less Harmful, April 2009

2624 Martin Ruf and Alfons J. Weichenrieder, The Taxation of Passive Foreign Investment Lessons from German Experience, April 2009 
2625 Yao Li, Borders and Distance in Knowledge Spillovers: Dying over Time or Dying with Age? - Evidence from Patent Citations, April 2009

2626 Jim Malley and Ulrich Woitek, Technology Shocks and Aggregate Fluctuations in an Estimated Hybrid RBC Model, April 2009

2627 Jin Cao and Gerhard Illing, Endogenous Systemic Liquidity Risk, April 2009

2628 Thiess Buettner and Bjoern Kauder, Revenue Forecasting Practices: Differences across Countries and Consequences for Forecasting Performance, April 2009

2629 Håkan Selin, The Rise in Female Employment and the Role of Tax Incentives - An Empirical Analysis of the Swedish Individual Tax Reform of 1971, April 2009

2630 Nick Johnstone and Ivan Hascic, Environmental Policy Design and the Fragmentation of International Markets for Innovation, April 2009

2631 Spiros Bougheas, Richard Kneller and Raymond Riezman, Optimal Education Policies and Comparative Advantage, April 2009

2632 Jay Pil Choi and Heiko Gerlach, Multi-Market Collusion with Demand Linkages and Antitrust Enforcement, April 2009

2633 Thor O. Thoresen, Income Mobility of Owners of Small Businesses when Boundaries between Occupations are Vague, April 2009

2634 Guido Schwerdt and Amelie C. Wuppermann, Is Traditional Teaching really all that Bad? A Within-Student Between-Subject Approach, April 2009

2635 Kurt R. Brekke, Luigi Siciliani and Odd Rune Straume, Hospital Competition and Quality with Regulated Prices, April 2009

2636 Peter Diamond, Taxes and Pensions, April 2009

2637 Shoshana Grossbard, How "Chicagoan” are Gary Becker's Economic Models of Marriage?, May 2009

2638 Roland Strausz, Regulatory Risk under Optimal Incentive Regulation, May 2009

2639 Holger Zemanek, Ansgar Belke and Gunther Schnabl, Current Account Imbalances and Structural Adjustment in the Euro Area: How to Rebalance Competitiveness, May 2009

2640 Harald Hau and Marcel Thum, Subprime Crisis and Board (In-)Competence: Private vs. Public Banks in Germany, May 2009

2641 Martin Halla, Mario Lackner and Friedrich G. Schneider, An Empirical Analysis of the Dynamics of the Welfare State: The Case of Benefit Morale, May 2009

2642 Balázs Égert, Infrastructure Investment in Network Industries: The Role of Incentive Regulation and Regulatory Independence, May 2009 
2643 Christian Gollier, Expected Net Present Value, Expected Net Future Value, and the Ramsey Rule, May 2009

2644 Sören Blomquist and Håkan Selin, Hourly Wage Rate and Taxable Labor Income Responsiveness to Changes in Marginal Tax Rates, May 2009

2645 Dominique Demougin, Oliver Fabel and Christian Thomann, Implicit vs. Explicit Incentives: Theory and a Case Study, May 2009

2646 Francesco C. Billari and Vincenzo Galasso, What Explains Fertility? Evidence from Italian Pension Reforms, May 2009

2647 Kjell Arne Brekke, Karen Evelyn Hauge, Jo Thori Lind and Karine Nyborg, Playing with the Good Guys - A Public Good Game with Endogenous Group Formation, May 2009

2648 Guglielmo Maria Caporale and Luis A. Gil-Alana, Multi-Factor Gegenbauer Processes and European Inflation Rates, May 2009

2649 Henning Bohn, A Static Model for Voting on Social Security, May 2009

2650 Markus Haavio and Kaisa Kotakorpi, The Political Economy of Sin Taxes, May 2009

2651 Augusto de la Torre, María Soledad Martínez Pería and Sergio L. Schmukler, Drivers and Obstacles to Banking SMEs: The Role of Competition and the Institutional Framework, May 2009

2652 Tobias Lindhe and Jan Södersten, Dividend Taxation, Share Repurchases and the Equity Trap, May 2009

2653 Assaf Razin and Edith Sand, Migration-Regime Liberalization and Social Security: Political-Economy Effect, May 2009

2654 Yin-Wong Cheung and Hiro Ito, A Cross-Country Empirical Analysis of International Reserves, May 2009

2655 Bart Cockx and Bruno Van der Linden, Flexicurity in Belgium. A Proposal Based on Economic Principles, May 2009

2656 Michael Melvin, Lukas Menkhoff and Maik Schmeling, Exchange Rate Management in Emerging Markets: Intervention via an Electronic Limit Order Book, May 2009

2657 Susanne Neckermann, Reto Cueni and Bruno S. Frey, What is an Award Worth? An Econometric Assessment of the Impact of Awards on Employee Performance, May 2009

2658 Steven Brakman, Harry Garretsen and Charles van Marrewijk, Economic Geography within and between European Nations: The Role of Market Potential and Density across Space and Time, May 2009 